\title{
LANGKAH PENYADARAN BRAND USAHA KECIL DAN MENENGAH (UKM)
}

\author{
Noor Udin \\ Jurusan Desain Komunikasi Visual, Fakultas Komunikasi dan Multimedia, Bina Nusantara University \\ Jln. K.H. Syahdan No. 9, Kemanggisan, Palmerah, Jakarta Barat 11480
}

\begin{abstract}
Brand is an abstract term for actors in small and medium enterprises (SME). Moreover, it is hard to attach the term into understanding how they need branding. Understanding brand design is one step to synchronize the mind set of SME actors to map the business range, product understanding, and also their target market and other things related to their business. A good identity for an SME brand will create brand core value collaborated by complete understanding about entity aspects that having special ecosystem and unique. If thinking about long-term, SME actors will get many advantages from branding activity. Therefore, selling-based and branding activities are better moving together and strengthen each other.
\end{abstract}

Keywords: branding, SME, selling, brand awareness

\begin{abstract}
ABSTRAK
Brand, oleh kebanyakan pelaku Usaha Kecil Menengah (UKM), merupakan istilah yang tidak terbayang oleh mereka. Apalagi memasukkan istilah itu ke dalam bahkan meyertakan pemahaman tentang mengapa mereka memerlukan sebuah brand. Memahamkan desain brand merupakan langkah menyelaraskan pola pikir para pelaku UKM dalam memetakan lingkup usaha, memahami produk, dan juga memahami pasar mereka serta segala hal yang berkait dengan keseluruhan lini usaha mereka. Identitas yang baik bagi sebuah brand UKM akan terbentuk dari nilai inti brand dikolaborasikan dengan pemahaman yang lengkap tentang unsur entitas yang memiliki Ekosistem yang khas dan kepribadian unik. Jika memikirkan jangka panjang, pengusaha UKM akan mendapatkan banyak keuntungan dari aktivitas branding. Jadi, aktivitas berbasis penjualan dan kegiatan untuk branding, sebaiknya bisa berjalan beriringan dan saling menguatkan.
\end{abstract}

Kata kunci: branding, UKM, penjualan, penyadaran tentang brand 


\section{PENDAHULUAN}

Dalam bebepa kesempatan bertemu dengan para pelaku UKM semisal seminar dan workshop pemasaran, ada keseragaman pemahaman diantara mereka. Pada umumnya mereka memiliki visi yang besar bagi pengembangan usaha atau produknya, sebut saja mereka sebenarnya telah memiliki kesadaran branding (brand awareness) namun istilah branding tidak terbiasa ada dibenak mereka.

Tahun 2010 penulis berkesempatan membantu Kementrian Perdagangan RI memberikan materi penyadaran branding kepada para pelaku UKM di Pusdiklat Kementrian Perdagangan RI di kawasan Depok, yang menakjubkan, mereka telah melampaui langkah-langkah branding modern (Udin, 2010). Di antaranya adalah perencanaan produk, merencanakan positioning dan merencanakan identitas produk mereka melalui desain packaging dan logo. Lagi-lagi istilah branding belum juga disadari bahwa mereka telah melakukan salah satu dari proses branding.

Berikut di antara beberapa poin pemahaman dan penyadaran branding kepada para pelaku UKM, yaitu: (1) brand bukan logo, pemahaman mendasar bagi para pelaku UKM bahwa brand hanyalah logo/symbol saja. Jadi sebagian dari mereka telah merasa cukup jika usaha yang dibangunnya telah memilki logo. Karena dengan logo, kop surat, kartu nama, sign board telah mampu mengkomunikasikan bisnis mereka. (2) Brand adalah visi dan komitmen, yang menjadi titik tolak perjuangan. Usaha UKM akan mempunyai mata panah yang tajam ke segala arah. Jelaslah di sini sebuah usaha UKM kelak harus mampu membri perubahan yang berarti bagi komunitas konsumen dan komunitas social yang lebih besar, bahkan para kompetitornya. (3) Brand adalah janji, poin melebarkan pemahaman para pelaku UKM bahwa brand mempunyai lingkup tanggung jawab besar, sebuah gagasan bisnis UKM ternyata tidak berhenti ketika terjadi transaksi jual beli dimana rantai bisnis telah putus begitu saja. Namun brand merupakan ide besar yang ekspektasi dan reputasinya akan selalu hadir di benak konsumen sampai kapanpun. (4) Brand adalah tangan untuk merangkul konsumen, poin ini menggambarkan bahwa usaha UKM bukan hanya bermakna produk yang real atau rasional, melainkan harus merampah sector emosi, bias berwujud kesan, pengalaman, dan hadir di dalam kehidupan konsumen. Emosional adalah faktor yang paling mempengaruhi seseorang pada saat menghadapi pilihan dan mengambil keputusan.

\section{Mengajak Pelaku UKM Memahami Target Audience dan Konsumen}

Mengenali target audience merupakan kondisi paling aktual dalam usaha UKM, karena brand adalah sesuatu yang sangat lekat di benak audience. Berbagai variabel tentang Target Audience dapat kita identifikasi dari jatidiri, budaya, aktivitas, kebiasaan komunitas, pendapatan/income, strata social dan ekonomi, pendidikan dari target audience/konsumen. Langkah identifikasi ini sangat menentukan pemahaman hubungan timbal balik dengan brand UKM. Audience atau consumer insight merupakan langkah pemahaman tentang berbagai bentuk keinginan audiens, sehingga dapat dipenuhi oleh brand. Kegiatan ini bisa dimulai dengan riset kecil pada lingkup bisnis UKM. Manfaat dari pemahaman mengenai Target Audience iniu akan menghasilkan keunikan layanan dan inovasi produk. Karena bekerja atau tidaknya sebuah produk akan sangat bergantung dari keinginan dan kebutuhan Target Audience/konsumen. Sehingga kita akan mengenal istilah diferensiasi produk atau bahkan brand extension.

\section{Membangun Identitas UKM}

Setelah memahami dimensi kebutuhan, aspirasi dan inspirasi audiens. Langkah yang sangat penting berikutnya adalah merencanakan identitas Brand UKM. 

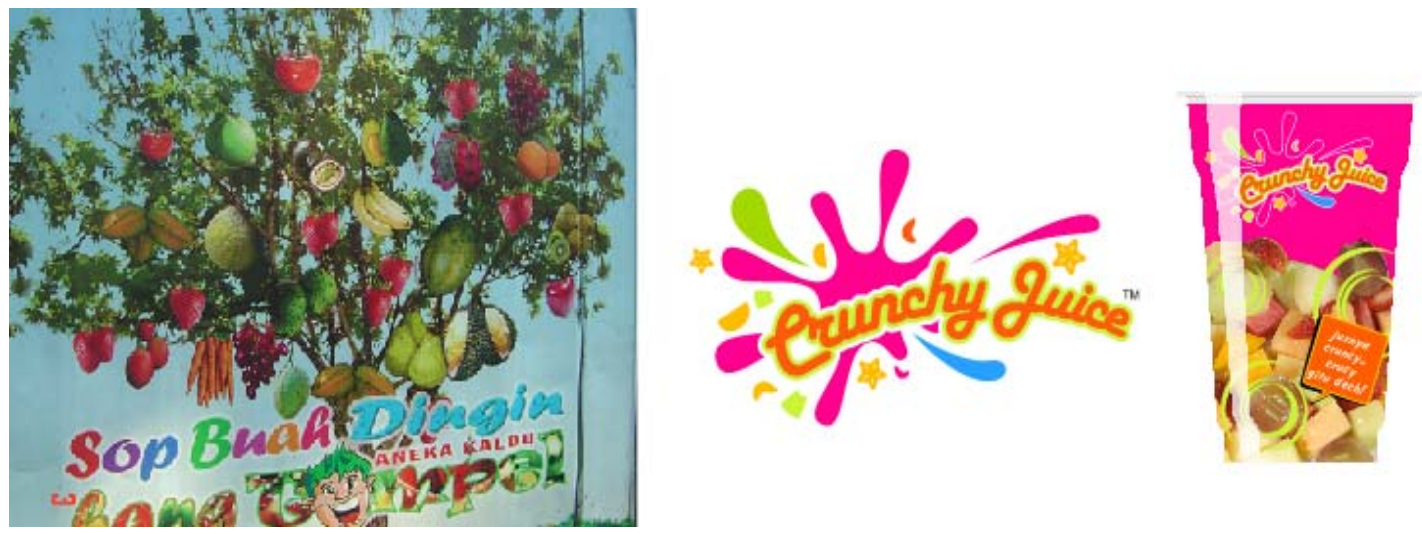

Gambar 1 Contoh Pengembangan Identitas UKM

Dari pemahaman dan kedekatan dengan konsumen brand UKM seharusnya sudah sangat mudah diterjemahkan menjadi identitas tersendiri yang unik. Identitas ini terbentuk dari sifat produk, benefit, tingkat kepercayaan konsumen, keinginan konsumen dan hubungan emosional yang terjalin dengan konsumen. Atribut inilah yang akan menjadi kekuatan identitas komunikasi kepada target audience/konsumen. Dengan memahami konsumen brand UKM akan diidenfikasikan dengan kaca mata konsumen/direspon oleh konsumen, bukan hasil dari pemaksaan pelaku UKM.

Identitas yang baik bagi sebuah brand UKM akan terbentuk dari core value/nilai inti brand dikolaborasikan dengan pemahaman yang lengkap tentang unsur entitas yang memiliki Ekosistem/nature business yang khas dan kepribadian unik; dilengkapi oleh pemahaman audience yang focus dengan aspirasinya; dilengkapi pemahaman hubungan entitas dan audience yang saling bermanfaat, menghasilkan nilai kepercayaan, sehingga identitas menjadi sangat unik dan menghasilkan esensi dari brand.

\section{PEMBAHASAN}

\section{Menjual Brand Lebih Efektif Daripada Menjual Produk}

Minimnya pemahaman tentang branding atau merek. Semuanya sudah memiliki merek, tapi masih memandangnya sekadar label belaka, bukan sebagai bagian dari strategi pemasaran. Kegiatan branding memang dikenal sebagai sumber biaya (cost center) bukan sumber laba (profit center,) sehingga keberadaannya kurang diindahkan oleh pengusaha UKM. Dengan kondisi UKM yang masih terbatas secara modal, jumlah produksi dan SDM, manakah yang lebih tepat, lebih banyak melakukan aktivitas penjualan ataukah membangun merek? Komprominya ialah lakukan penjualan secara eceran untuk membangun merek dan mulailah menjual ke pasar B2B untuk mendapatkan penjualan yang lebih besar. Kedua aktivitas ini idealnya dilaksanakan secara beriringan, bukan untuk saling mengalahkan. Pasar bisnis ke bisnis, lebih menghasilkan volume penjualan besar tapi dengan keuntungan tipis. Sementara, penjualan eceran akan memberikan keuntungan yang lebih besar serta memungkinkan pembangunan merek produk.

\section{Di Era New Wave UKM dapat Mengadopsi Strategi Branding Merk Besar}

Beda dulu, beda sekarang. Bila dulu media konfensional menjadi sarana wajib bagi komunikasi untuk membangun brand awareness yang paling efektif, namun di era digital ini, para 
pelaku UKM bias lebih leluasa berbagai media. Biro-biro iklan dan komunitas Creative Branding Consultant menggunakan media-media alternatif yang mampu menjangkau jantung audience-nya. Media alternatif tersebut terdiri dari jaringan digital atau network, internet, jejaring sosial dan cetak bahkan dalam dasawarsa terakhir sering kita kenal dengan media lingkungan atau ambient media. Tentu saja efektivitas media di atas menuntut kreatifitas para pelaku UKM dalam menentukan kekhasan pesan dan pendekatan komunikasi di berbagai media tersebut. Siapa yang paling memikat dialah yang akan tampil sebagai pemenang di tengah persaingan yang tidak juga diramaikan para pelaku UKM namun juga brand-brand besar dengan kategori produk yang sama.

Gerilya pemasaran salah satu contoh kreatif yang bisa dilakukan untuk menyiasati persaingan yang dahsyat tersebut, selain menghemat anggaran, juga sangat mungkin menggerogoti lawan dan memberikan hasil yang maksimal, seperti community development melalui berbagai kanal media (konvensional dan digital), menggabungkan brand lain yang saling berkomplementer (co-branding), aktivitas sosial, aktivitas ritel dan sebagainya. Tentu saja para pelaku UKM harus mendapat pendampingan yang cukup untuk mampu menjalankan strategi tersebut. Maka pemerintah ataupun department terkait sekiranya harus mampu menjadi sarana pencetus strategi branding bagi UKM yang mampu menjawab tantangan jaman.

\section{PENUTUP}

Membangun brand adalah sebuah proses, perlu waktu dan biasanya melalui enam tahap sebelum memungkinkan terjadinya penjualan berkesinambungan, yaitu: (1) tahap pengenalan (aware); (2) tahap mengerti benefit atau positioning (understand); (3) tahap meyakinkan bahwa produk lebih baik dari pesaing (preference); (4) tahap membangkitkan semangat mencoba, membeli secepatnya (convince); (5) tahap terciptanya penjualan (action/selling); (6) tahap pembelian kembali (repeat). Jika pengusaha UKM memandang secara jangka pendek, tentu saja branding bukan pilihan yang populer. Tapi, kalau saja bisa memikirkan jangka panjang, pengusaha UKM akan mendapatkan banyak keuntungan dari aktivitas branding. Jadi, aktivitas berbasis penjualan dan kegiatan untuk branding, sebaiknya bisa berjalan beriringan dan saling menguatkan. Bagaimana menurut Anda?

\section{DAFTAR PUSTAKA}

Udin, N. (2010). Biarkan desain bekerja: Alasan-alasan sederhana mengapa UKM membutuhkan desain yang baik. Dalam Kiat-kiat pemasaran UKM. Jakarta: Pusdiklat Departemen Perdagangan RI.

Wheeler, A. (2003). Designing brand identity: A complete guide to creating, building, and marketing strong brand (2nd ed.). USA: John Wiley and Sons. 